P. Goris

T. D. Morgan

R. A. Nielsen

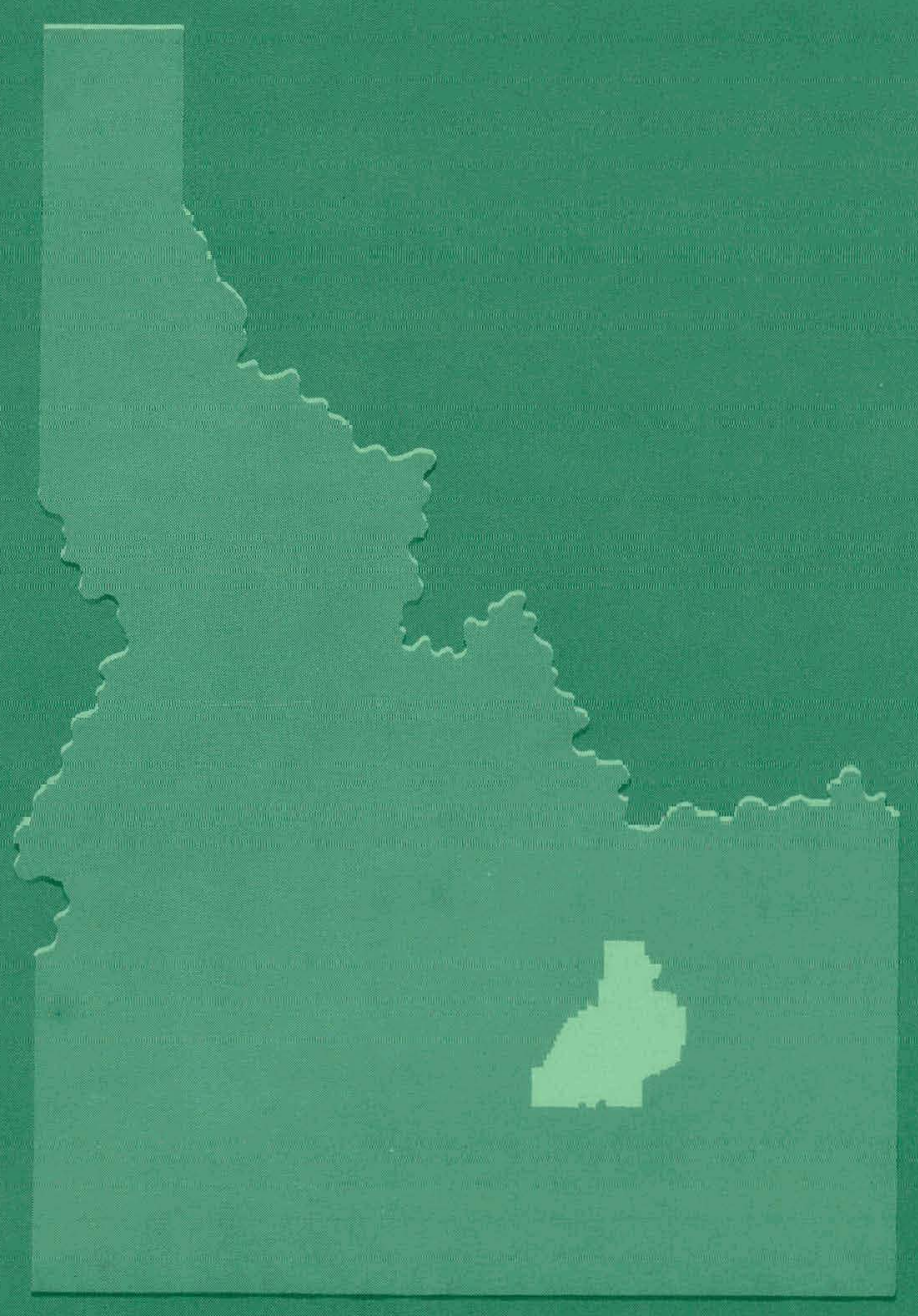

PHILLIPS PETROLEUM COMPANY

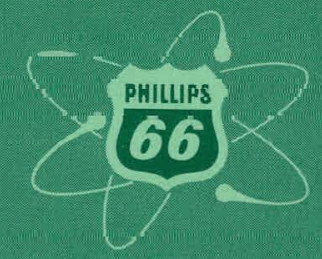

ATOMIC ENERGY DIVISION

NATIONAL REACTOR TESTINE STATION US ATOMIC ENERGY COMMISSION 


\section{DISCLAIMER}

This report was prepared as an account of work sponsored by an agency of the United States Government. Neither the United States Government nor any agency Thereof, nor any of their employees, makes any warranty, express or implied, or assumes any legal liability or responsibility for the accuracy, completeness, or usefulness of any information, apparatus, product, or process disclosed, or represents that its use would not infringe privately owned rights. Reference herein to any specific commercial product, process, or service by trade name, trademark, manufacturer, or otherwise does not necessarily constitute or imply its endorsement, recommendation, or favoring by the United States Government or any agency thereof. The views and opinions of authors expressed herein do not necessarily state or reflect those of the United States Government or any agency thereof. 


\section{DISCLAIMER}

Portions of this document may be illegible in electronic image products. Images are produced from the best available original document. 
PRICE $\$ .50$

Available from the Office of Technical Services U. S. Department of Commerce Washington 25, D. C.

\section{LEGAL NOTICE}

This report was prepared as an account of Government sponsored work. Neither the United States, nor the Commission, nor any person acting on behalf of the Commission:

A. Makes any warranty or representation, express or implied, with respect to the accuracy, completeness, or usefulness of the information contained in this report, or that the use of any information, apparatus, method, or process disclosed in this report may not infringe privately owned rights; or

B. Assumes any liabilities with respect to the use of, or for damages resulting from the use of any information, apparatus, method, or process disclosed in this report.

At used in the ahove, "person acting on behalt of the Lommiosion" includes any employee or contractor of the Commission, or employee of such contractor, to the extent that such employee or contractor of the Commission, or employee of such contractor prepares, disseminates, or provides access to, any information pursuant to his employment or contract with the Commission, or his employment with such contractor. 


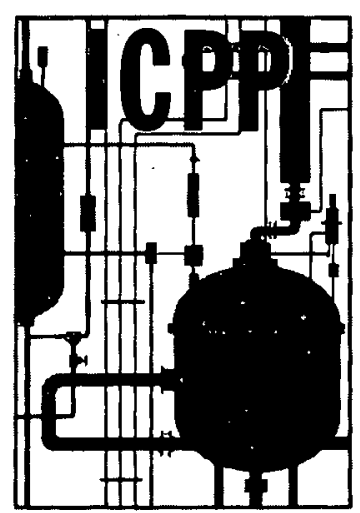

IDO-14549 AEC Research and Development Report Chemistry TID-4500, Ed. 16

IDAHO CHEMICAL PROCESSING PLANT

R. C. Shank, Supervisor, Analytical Chemistry Section

COMPARATIVE BORON ISOTOPIC ANALYSIS

By

P. Goris, T. D. Morgan, R. A. Nielsen

PHILLIPS

PETROLEUM

COMPANY

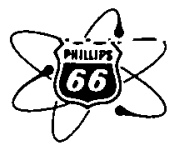

Atomic Energy Division

Contrast AT(10.1)-205

Idaho Operations Office

U. S. ATOMIC ENERGY COMMISSION 


\title{
COMPARATIVE BORON ISOTOPIC ANALYSIS
}

\section{By}

P. Goris, T. D. Morgan, R. A. Nielsen

\section{A B S T R A C T}

\begin{abstract}
Surface ionization results for natural boron isotopic analysis
are in agreement with other recent investigations indicating a $\mathrm{B}^{11 / \mathrm{B}^{10}}$ atom ratio nearer to 4.00 than the more commonly accepted value of 4.31 based on $\mathrm{BF}_{3}$ analysis.
\end{abstract}

Work done under Contract AT(10-1)-205 to the U. S. Atomic Energy Commission. 
COMPARATIVE BORON ISOTOPIC ANALYSIS

TABLE OF CONTENTS

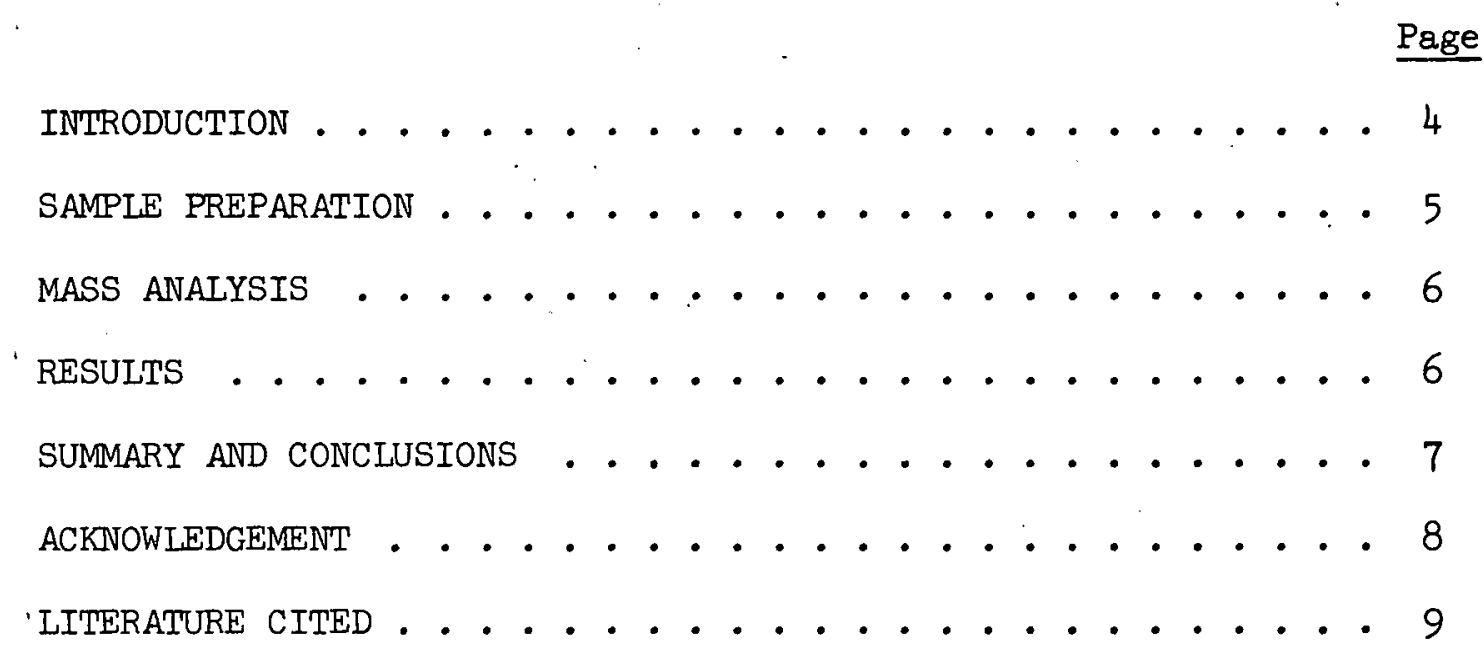




\section{COMPARATIVE BORON ISOTOPIC ANALYSIS}

By

P. Goris, T. D. Morgan, R. A. Nielsen

\section{INTRODUCTION}

The isotopic abundance of natural boron is of interest because of its wide use as a standard neutron absorber. There has not been recent general agreement in the field concerning the $\mathrm{B}^{11} / \mathrm{B}^{10}$ ratio of natural boron. Inghram (1) reported a value of 4.31 based on mass spectrometric analysis of boron trifluoride, a compound noted for its adsorption characteristics resulting in "instrument memory". Since publication of that work a number of attempts to verify the abundance ratio with boron trifluoride have resulted in a wide range of values. More recent work with gaseous boron hydrides, trimethylboroxine(2), and methyl borate ${ }^{(3)}$ as well as surface ionization work at $\mathrm{KAPL}(10,11)$ indicate that a $\mathrm{B}^{11} / \mathrm{B}^{10}$ atom ratio of 4.00 approaches the true natural abundance ratio more closely than the accepted value of 4.31 .

Thode and his co-workers detected small variations in the relative abundance of the boron isotopes $\mathrm{B}^{10}$ and $\mathrm{B}^{11}$ in natural materials. (4)

Variations in natural lithium isotopes have been reported by Cameron. (5) In this report the hypothesis is given that variations in both natural boron and lithium isotopic abundance may be due to neutron exposure since both elements possess isotopes of large capture cross seclluns. However, because of demonstrated changes from precipitation reactions in the isotopic ratio of lithium, these variations may well be ascribed to chemical effects according to Cameron. 
A more recent study on variations in relative abundance of boron isotopes in nature indicated constancy in the isotopic composition of boron. (6) These workers suggested that chemical preparation of boron trifluoride in the work of Thode et. al. may account for their observed variations.

In view of the wide range of values reported for the $\mathrm{B}^{11 / \mathrm{B}^{10}}$ ratio, and the remaining uncertainty as to variation of boron isotopes in nature, the authors are of the opinion that more work in boron isotopic analysis by surface ionization mass spectrometry is worthwhile. The technique is based on $\mathrm{Na}_{2} \mathrm{BO}_{2}{ }^{+}$emission from a borax bead on the filament. (7) Tendency toward less "memory effects" in surface ionization instruments offers an important advantage.

The work described in this report was initiated on behalf of Reactor Technologists at the NRTS in connection with their uses of natural boron as a standard neutron absorber. (8). Objectives of the program with emphasis on surface ionization mass spectrometry were as follows:

1. To obtain samples of material other laboratories have analyzed and are using as standards in order to compare their results with ICPP results.

2. To calibrate an appropriate boron-containing material for use as standard at the NRTS.

\section{SAMPLE PREPARATION}

Boron materials were obtained for this study in the form of sodium tetraborate and boric acid crystals. Boric acid was converted to the tetraborate with sodium carbonate of less than 0.0002 wt. \% boron according to spectrographic andiysis. It was found that impure borax beads 
give emission of short duration, possibly because of poor bonding with the filament or low ionization efficiency. Stoichiometric amounts of boric acid and sodium carbonate were therefore mixed followed by several recryotallizations in water to minimize foreign materials in prepared borax. Emission is especially stable and lasting if the borax bead has a clear, glassy appearance after heating on the filament.

\section{MASS ANALYSIS}

Fundamentally the mass spectrometer used in this investigation is a 12-inch radius, 60 degree, direction-focusing instrument equipped with a vacuum lock for the introduction of solid samples without undue loss of vacuum. The instrument is described by Stevens and Inghram. (9) The signal from the ion collector is amplified by use of an Applied Physics vibrating reed electrometer and Brown-Electronik recorder,

The $\mathrm{Na}_{2} \mathrm{BO}_{2}{ }^{+}$spectrum from borax is observed at comparatively low filament temperatures. Tantalum ribbon $0.001 " \mathrm{x} 0.030^{\prime \prime}$ is channeled with a special jig, and pure borax on the filament is heated openly to form a clear, glassy bead in the channel. Emission from a pure borax bead is ideal for accurate results. Beam intensity can be maintained at high levels for long periods. A small correction for $0^{17}$ on the 89 peak due to the ion $\left(\mathrm{Na}_{2} \mathrm{~B}^{10} \mathrm{O}^{16_{0}}{ }^{17}\right)^{+}$can be applied if necessary.

\section{RESULTS}

Natural boron standards analyzed by surface ionization techniques were obtained from KAPL and Hanford. A very accurate blend prepared at KAPL and used to investigate bias in their surface ionization technique (10) was also obtained. An abundant supply of boric acid (Baker-Analyzed, 
Lot No. 92308) was obtained as the NRTS standard. All results are summarized in Table $I$.

TABLE I. COMPARATIVE RESULTS OF BORON ISOTOPIC ANALYSIS BY SURFACE IONIZATION

(Precision limits for average values are at the 95\% confidence level)

SAMPIE

KAPL-Normal Boron

Hanford-Normal Boron

KAPL-*Enriched Boron $\mathrm{B}^{11} / \mathrm{B} 10=3.661 \pm 0.007$ by blending

Normal Boric Acid-"BakerAnalyzed" Lot No. 92308

* Ref. (10)

** Ref. (12)
AVE. ATOM RATIO $\mathrm{B}^{11} / \mathrm{B}^{10}$
KAPI Anal.

$* 4.041 \pm 0.06$

Hanford Anal.

KAPL Anal.

*3.657 \pm 0.08 $* \overline{4.173 \pm 0.04}$
ICPP Anal.

$4.044 \pm 0.06$

ICPP Anal. $4.017 \pm 0.04$

ICPP Anal. $3.666 \pm 0.05$
ICPP Anal. $\frac{10000 \pm 0.06}{4.000 \pm 0}$

\section{SUMMARY AND CONCLUSIONS}

Table I shows that surface ionization techniques at KAPL and ICPP agree very well within experimental limits on natural and blended boron standards.

It is particularly significant that the blended standards mass data from both locations agree with the known values and that both sets of values for a natural boron sample indicate a $\mathrm{B}^{11} / \mathrm{B}^{10}$ ratio of nearly 4.00 in agreement with several recent studies. The use of $99.9 \% \mathrm{~B}^{10}$ and $98.5 \% \mathrm{~B}^{11}$ in blending the standards at $\mathrm{KAPL}$ resulted in nearly absolute standards, with known uncertainties in $\mathrm{B}^{11} / \mathrm{B}^{10}$ ratios. 
The ICPP results for the Hanford boron standard are not significantly different from other normal results listed in Table I, although no explanation is offered for the significant difference between Hanford and ICPP results.

No conclusions regarding variation of isotopic abundance in nature are made for this report because of the limited number of samples analyzed. However, the authors are of the opinion that an extensive investigation should be carried out with surface ionization techniques. Results give some assurance that a $\mathrm{B}^{11} / \mathrm{B}^{10}$ atom ratio of approximately 4.00 can be expected from randomly selected natural boron samples; therefore, the experimental value of $4.00 \pm 0.06$ is recommended to the Reactor Technologists at NRTS for the normal boron standard available from this laboratory.

\section{ACKNOWLEDGEMENT}

The authors are grateful to Harlan J. Anderson of Hanford and T. Leo Collins, Jr. of KAPL for furnishing boron standards and results so that a comparison of surface ionization techniques would be possible. Appreciation is extended to those who were willing to participate similarly but lacked suitable standards at the time of reply. 


\section{LITERATURE CITED}

1. Inghram, M., Phys. Rev., 70, 653 (1946).

2. Nature, Vol. 183, p. 1324, May 9, 1959.

3. Abernathey, R. M., IDO-14503, Jan., 1960.

4. Thode, H. G., MacNamara, J., Lossing, F. P., Collins, C. B., Jour. Amer. Chem. Soc., 70, 3008 (1948).

5. Cameron, A. E., K-1168, Sept., 1954.

6. Parwel, A., Von Ubisch, H., Wickman, F. E., Geochimica et Cosmochimica Acta, 1956 Vol. 10, pp. 185-190.

7. Palmer, G. H., J. Nuclear Energy, 1958, Vol. 7, pp. 1 to 12.

8. Private communication, E. Fast, Phillips Petroleum Co., AEC, Aug., 1960.

9. Stevens, C. M., Inghram, M. G., U. S. A. E. C. Rept. ANL-3251 (1954).

10. Haas, W. D. Jr., Rourke, F. M., Mewherter, J. L., McDonald, P. H., KAPL-2062, Oct. , 1959.

11. Private communication, T. Leo Collins, Jr., KAPL.

12. Private communication, Harlan J. Anderson, Hanford. 


\section{PHILLIPS}

PETROLEUM

COMPANY

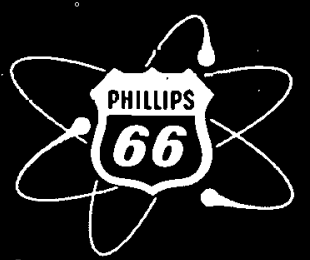

ATOMIC ENERGY DIVISION 